\title{
STRATEGI PENGEMBANGAN USAHA PEMASARAN DAGING SAPI (Bos taurus ) DI KECAMATAN KUALA SIMPANG KABUPATEN ACEH TAMIANG
}

\author{
${ }^{1}$ Muslimah, S.Si,M.Si/Nuzul Azmi \\ ${ }_{1}^{1}$ Dosen Tetap Program Studi Agribisnis Fakultas Pertanian \\ ${ }^{2}$ Mahasiswa Fakultas Pertanian Program Studi Agribisnis \\ Universitas Samudra, Langsa-Aceh
}

\begin{abstract}
ABSTRAK
Penelitian ini dilaksanakan di Kecamatan Kuala Simpang Kabupaten Aceh Tamiang dengan menggunakan metode survey. Objek penelitian ini adalah pedagang daging, dinas perdagangan, dinas pertanian dan peternakan dan akademisi. Ruang lingkup penelitian ini dibatasi pada strategi pengembangan usaha pemasaran daging sapi di Kecamatan Kuala Simpang dengan analisis SWOT (Strength, Weakness, Opportunity dan Treath). Penelitian dilaksanakan pada bulan Maret s/d April 2015.

Di Pasar Kuala Simpang terdapat 24 pedagang daging sapi. Seluruhan populasi pedagang daging yang ada secara purposive sampling (sengaja) dijadikan sebagai sampel atau sampel jenuh ditambah 5 orang tokoh kunci.

Hasil analisis faktor-faktor strategis internal pengembangan pemasaran daging sapi di Kecamatan Kuala Simpang terdiri dari; 1) Faktor kekuatan: Produk daging sapi berkualitas, Tenaga kerja tersedia, Peralatan semi modern, Kapasitas produksi besar, Pelayanan pasar yang baik dan Adanya manajemen mutu. 2) Faktor kelemahan:, Produksi daging sapi belum optimal, Kurangnya promosi, Harga jual daging sapi relatif tinggi dan Biaya produksi daging sapi makin mahal.

Hasil analisis faktor-faktor strategis eksternal pengembangan pemasaran daging sapi di Kecamatan Kuala Simpang terdiri dari; 1) Faktor peluang: Meningkatnya permintaan daging sapi, Meningkatnya pendapatan konsumen, Meningkatnya konsumsi daging sapi konsumen, Pertumbuhan ekonomi membaik, Hubungan baik dengan pemasok dan Potensi pengembangan ternak sapi. 2) Faktor ancaman: Naik turunya nilai tukar rupiah, Inflasi (kenaikkan harga barang), Naiknya harga BBM, Adanya barang pengganti, Daging sapi impor.

Hasil analisis SWOT alternatif prioritas yang ditawarkan dalam rangka pengembangan pemasaran daging sapi di Kecamatan Kuala Simpang adalah: Meningkatkan kerjasama dengan pemasok agar mendapatkan harga yang kompetitif, Meningkatkan kwalitas SDM peternak sapi lokal, Mengadakan perluasan pasar daging sapi, Mengembangkan sistem pemasaran yang bisa mencukupi semua kebutuhan konsumen, Mengembangkan promosi dan peternakan sapi untuk meningkatkan pasokan daging sapi lokal yang berkualitas, Membentuk koperasi pedagang daging sapi agar tidak ada perbedaan harga yang terlalu besar, Meningkatkan sosialisasi manfaat daging sapi lokal, Meningkatkan permintaan daging sapi dengan menciptakan produk berbasis daging sapi
\end{abstract}

Kata Kunci: Faktor Internal, Faktor Eksternal, Strategi, Prioritas, Pemasaran, Daging Sapi

\section{PENDAHULUAN}

Permintaan pangan hewani terutama daging sapi meningkat cukup besar sejalan dengan laju pertumbuhan penduduk baik pada tingkat nasional maupun wilayah provinsi. Untuk memenuhi permintaan daging sapi tersebut, Direktorat Jenderal Peternakan telah mencanangkan Program Percepatan Pencapaian Swasembada Daging Sapi (P2SDS) yang difokuskan di 18 Provinsi sentra sapi potong termasuk Aceh (Anonimous, 2007:24).

Daging merupakan komponen utama karkas yang tersusun dari lemak, jaringan adipose tulang, tulang rawan, jaringan ikat dan tendon. Komponen-komponen tersebut menentukan ciri-ciri kualitas daging, organ-organ misalnya hati, ginjal. Otak, paru-paru, jantung, limpa, pankreas dan jaringan otot tidak termasuk dalam definisi ini. Daging ternak mamalia umumnya termasuk daging sapi disebut daging merah. Warna merah yang terdapat pada daging-daging tersebut disebabkan oleh kandungan dari mioglobin. Mioglobin adalah protein yang membawa oksigen pada jaringan hewan ternak. Berikut AGRISAMUDRA, Jurnal Penelitian Vol.2 No. 2 Juli-Desember 2015 disajikan kandungan nilai gizi daging sapi.Tabel di atas menunjukkan bahwa kandungan tertinggi nilai gizi daging sapi adalah protein sebanyak 18,8 gram per 100 gram daging sapi. Sedangkan kandungan nilai gizi terendah adalah Vitamin B1 sebanyak 0,08 miligram per 100 gram daging sapi segar.

Pemasaran sebagaimana diketahui, adalah inti dari sebuah usaha. Tanpa pemasaran tidak ada yang namanya perusahaan, akan tetapi apa yang dimaksud dengan pemasaran itu sendiri orang masih merasa rancu. Pengertian pemasaran menurut Kotler (1997:8) adalah Suatu proses social dan manajerial yang didalamnya individu dan kelompok mendapatkan apa yang mereka butuhkan dan inginkan dengan menciptakan, menawarkan dan mempertukarkan produk dengan pihak lain “.

Banyak yang menganggap bidang ini identik atau sama dengan bidang penjualan. Sesungguhnya pemasaran memiliki arti yang luas daripada penjualan. Bidang penjualan merupakan bagian dari bidang pemasaran, sekaligus merupakan bagian terpenting dari bidang pemasaran itu sendiri. Pemasaran berarti bekerja dengan pasar untuk mewujudkan 
pertukaran potensial dengan maksud memuaskan kebutuhan dan keinginan manusia. Jika perusahaan menaruh perhatian lebih banyak untuk terus menerus mengikuti perubahan kebutuhan dan keinginan baru, mereka tidak akan mengalami kesulitan untuk mengenali peluang-peluangnya.

Karena para konsumen selalu mencari yang terbaik untuk kehidupannya dan tentu saja dengan harga yang terjangkau dan dengan kualitas yang baik pula, hal itulah yang memicu adanya persaingan yang semakin tajam yang menyebabkan para penjual merasa semakin lama semakin sulit menjual produknya di pasar. Sebaliknya, pihak pembeli merasa sangat diuntungkan karena mereka bebas memilih dari pihak manapun dengan kualitas dan mutu produk yang baik. Hal inilah yang mendorong para pakar bisnis untuk mencari jalan keluar yang terbaik. Fenomena masa lalu dipelajari dan dibandingkan dengan apa yang menggejala saat ini, kiat-kiat bisnis dalam memproduksi barang, menetapkan harga, mempromosikan serta mendistribusikan dinalisis dengan baik agar sesuai dengan tuntunan pasar.

Kabupaten Aceh Tamiang merupakan salah satu kabupaten yang ada di Propinsi Aceh yang memiliki letak strategis yang berbatasan langsung dengan Propinsi Sumatera Utara. Berkaitan dengan pemasaran daging sapi segar di daerah Aceh Tamiang terpusat di Pasar Kota Kuala Simpang sebagai pusat pemerintahan kabupaten. Pemasaran daging sapi segar di Kecamatan Kuala Simpang menunjukkan peningkatan dari tahun ke tahun.

Melihat potensi pemasaran daging sapi tersebut sudah selayaknya dipikirkan strategi pemasaran ke depan dengan mempertimbangkan faktor strategis internal dan eksternal. Faktor strategis internal mencakup faktor-faktor yang menjadi kekuatan dan kelemahan pemasaran daging sapi segar, sedangkan faktor strategis eksternal mencakup faktor-faktor yang menjadi peluang dan ancaman pemasaran daging sapi segar di Kecamatan Kuala Simpang Kabupaten Aceh Tamiang. Berdasarkan uraian latar belakang di atas maka penulis tertarik untuk melakukan penelitian tentang strategi pengembangan usaha pemasaran daging sapi di Kecamatan Kuala Simpang Kabupaten Aceh Tamiang.

\section{Identifikasi Masalah}

1. Apa saja yang menjadi faktor strategis internal dan eksternal pengembangan usaha pemasaran daging sapi di Kecamatan Kuala Simpang Kabupaten Aceh Tamiang?

2. Apa saja yang menjadi prioritas strategi dalam pengembangan usaha pemasaran daging sapi di Kecamatan Kuala Simpang Kabupaten Aceh Tamiang?
Tujuan penelitian

1. Untuk mengetahui faktor strategis internal dan eksternal pengembangan usaha pemasaran daging sapi di Kecamatan Kuala Simpang Kabupaten Aceh Tamiang.

2. Untuk mengetahui prioritas strategi dalam pengembangan usaha pemasaran daging sapi di Kecamatan Kuala Simpang Kabupaten Aceh Tamiang.

\section{METODE PENELITIAN}

Penelitian ini dilaksanakan di Kecamatan Kuala Simpang Kabupaten Aceh Tamiang dengan menggunakan metode survey. Ruang lingkup penelitian ini dibatasi pada strategi pengembangan usaha pemasaran daging sapi di Kecamatan Kuala Simpang dengan analisis SWOT (Strength, Weakness, Opportunity dan Treath). Penelitian dilaksanakan pada bulan Maret s/d April 2015.

\section{Penentuan Sampel dan Pengumpulan Data a. Penentuan Sampel}

Kecamatan Kuala Simpang mempunyai pasar daging yang terdiri dari banyak pedagang daging. Di Pasar Kuala Simpang terdapat 24 pedagang daging sapi. Metode penentuan sampel pedagang daging sapi menggunakan metode sensus (sampel jenuh), dimana seluruh populasi dijadikan sampel penelitian (Prasetyo dan Jannah, 2005:128).

Selanjutnya sampel dari tokoh kunci ditentukan secara sengaja (purposive sampling), dimana tokoh sampel yang ditunjuk memang memiliki kompetensi di daerah penelitian. Tokoh kunci sebanyak 5 orang terdiri dari sebagai berikut:

1) Kepala Dinas Pasar Kabupaten Aceh Tamiang

2) Kepala Dinas Pertanian dan Peternakan Kabupaten Aceh Tamiang

3) Ketua Pedagang Daging Sapi Pasar Kuala Simpang

4) Akademisi sebanyak 2 Orang

\section{b. Pengumpulan Data}

Sumber data penelitian merupakan faktor penting yang menjadi pertimbangan dalam menentukan metode pengumpulan data. Data yang digunakan dalam penelitian ini dapat dibagi menjadi dua jenis berdasarkan pada pengelompokkan yaitu: Data Primer dan Data Sekunder.

\section{Konsep dan Batasan Operasional}

a. Inventarisasi Faktor-faktor Strategis

Inventarisasi terhadap faktor-faktor strategis yang berpengaruh terhadap pengembangan usaha pemasaran daging sapi di Kecamatan Kuala Simpang.

b. Faktor-faktor Strategis Internal

Faktor-faktor strategis internal terdiri dari faktor kekuatan (Strengths) yaitu seluruh 
faktor-faktor yang menjadi kekuatan untuk pengembangan usaha pemasaran daging sapi dan faktor kelemahan (Weaknesses) yaitu seluruh faktor-faktor yang menjadi kelemahan untuk pengembangan usaha pemasaran daging sapi di Kecamatan Kuala Simpang.

c. Faktor-faktor Strategis Eksternal

Faktor-faktor strategis eksternal terdiri dari faktor peluang (Opportunities) yaitu seluruh faktor-faktor yang menjadi peluang dan ancaman (Threats) yaitu seluruh faktorfaktor yang menjadi ancaman dalam pengembangan usaha pemasaran daging sapi di Kecamatan Kuala Simpang.

d. Prioritas Strategi

Prioritas strategi adalah hasil dari evaluasi faktor-faktor strategis internal dan eksternal dengan memformulasikan strategi melalui matriks SWOT (Strengths Opportunities Weaknesses dan Threats) untuk mendapatkan alternatif strategi dalam pengembangan usaha pemasaran daging sapi di Kecamatan Kuala Simpang.

\section{Metode Analisis}

\section{Analisis EFI (Evaluasi Faktor Internal) dan EFE (Evaluasi Faktor Eksternal)}

Analisis ini memecahkan sebuah analisis lingkungan mengidentifikasi kekuatan (S), kelemahan (W), peluang (O) dan ancaman ( $\mathrm{T}$ ) yang ada yang akan mempengaruhi strategi pengembangan usaha pemasaran daging sapi di Kecamatan Kuala Simpang. Analisis EFI dan EFE dari hasil identifikasi SWOT diperoleh dari hasil wawancara dengan responden. Rumus penskoran EFI (Evaluasi Faktor Internal) dan EFE (Evaluasi Faktor Eksternal) yaitu:
$\mathrm{NS}=\mathrm{B} \times \mathrm{R}$

Dimana:

NS = Nilai Skor masing-masing Faktor

$\mathrm{R}$ = Rating masing-masing Faktor (1-4)

$\mathrm{B}=$ Bobot masing-masing Faktor $(0,0-1,0)$

\section{Analisis EFI}

Analisis EFI dilakukan untuk memperoleh faktor kekuatan yang dapat dimanfaatkan dan faktor kelemahan yang harus diatasi dengan matrik $\mathrm{EFI}$.

\section{Analisis EFE}

Analisis EFE dilakukan untuk mengetahui seberapa baik strategi yang telah dilakukan untuk melihat peluang dan ancaman yang ada dengan matrik EFE.

Dari hasil analisis EFE dapat dilihat apakah faktor-faktor peluang (0) nilai skornya lebih besar atau lebih kecil dari faktor-faktor ancaman (T) berarti mengetahui pengaruhnya dalam pengembangan pemasaran daging sapi di Kecamatan Kuala Simpang.

\section{Analisis matriks EFI/EFE dan pembuatan matriks SWOT}

Rumus matriks EFI/EFE yaitu:

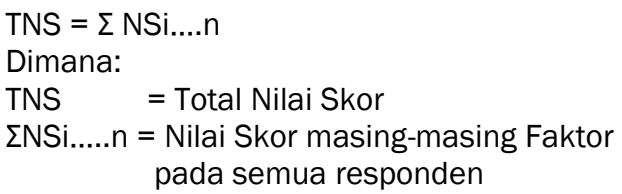

Berdasarkan matriks SWOT dapat dikembangkan beberapa alternatif strategi sebagai berikut :

Tabel II-4. Matriks SWOT

\begin{tabular}{|l|l|l|}
\hline \multicolumn{1}{|c|}{$\begin{array}{l}\text { Faktor } \\
\text { Internal } \\
\text { Eksternal }\end{array}$} & $\begin{array}{l}\text { Strengths (S) } \\
\text { Kekuatan }\end{array}$ & $\begin{array}{l}\text { Weaknesses (W) } \\
\text { Kelemahan }\end{array}$ \\
\hline $\begin{array}{l}\text { Opportunities (O) } \\
\text { Peluang }\end{array}$ & $\begin{array}{l}\text { Strategi SO } \\
\text { Penggunaan kekuatan } \\
\text { untuk memanfaatkan } \\
\text { peluang }\end{array}$ & $\begin{array}{l}\text { Minimalisasi kelemahan } \\
\text { dengan memanfaatkan } \\
\text { peluang }\end{array}$ \\
\hline $\begin{array}{l}\text { Threats }(T) \\
\text { Ancaman }\end{array}$ & $\begin{array}{l}\text { Strategi ST kenguatan } \\
\text { untuk mengatasi ancaman }\end{array}$ & $\begin{array}{l}\text { Minimalisasi kelemahan } \\
\text { dengan } \\
\text { ancaman }\end{array}$ \\
\hline
\end{tabular}

Analisis matriks SWOT menggunakan data yang telah diperoleh dari matriks EFI dan EFE. Empat strategi utama yang disarankan yaitu strategi SO (strength and opportunities), WO AGRISAMUDRA, Jurnal Penelitian Vol.2 No. 2 Juli-Desember 2015 (weakness and opportunities), ST (strength and threats) dan WT ( weakness and threats). Adapun hasil analisis matriks SWOT maka alternatif atau pilihan strategi yang dapat 
diberikan untuk pengembangan pemasaran daging sapi di Kecamatan Kuala Simpang.

\section{Pengambilan keputusan dari berbagai alternatif strategi.}

Setelah diperoleh beberapa alternatif strategi melalui tahap pencocokan, yaitu dengan menggunakan matriks EFI/EFE dan matriks SWOT, maka tahap akhir dari analisis formulasi strategi adalah pemilihan strategi yang terbaik. Adapun alat analisis yang digunakan pada tahap pengambilan keputusan ini adalah Matriks Perencanaan Strategi Kuantitatif (Quantitative Strategic Planning Matrix/QSPM). Teknik ini menggunakan input dari analisis tahap masukan dan hasil pencocokan dari analisis tahap pemaduan untuk menentukan secara objektif diantara alternatif strategi.

Pengambilan keputusan menggunakan rumus yaitu:

$\mathrm{TAS}=\overline{\mathrm{B}} \times \mathrm{AS}$

Dimana:

TAS $=$ Total Angka Ketertarikan

$\bar{B}=$ Bobot Rata-Rata masing-masing Faktor

AS = Angka Ketertarikan

Setelah didapat TAS maka dicari nilai STAS menggunakan rumus yaitu:

Dimana:

$$
\mathrm{STAS}=\sum \operatorname{TASi} \ldots \ldots \mathrm{n}
$$

STAS = Total Rata-Rata Angka Ketertarikan

$\Sigma$ TASi....n = Total Angka Ketertarikan semua responden (sampel)

$\mathrm{N}=$ Jumlah responden (sampel)

Alternatif strategi yang memiliki STAS tertinggi akan menjadi prioritas tertinggi dalam pengembangan usaha pemasaran daging sapi di Kecamatan Kuala Simpang, disusul alternatif strategi dengan nilai STAS di bawahnya sampai STAS terendah.

\section{HASIL DAN PEMBAHASAN}

\section{Inventarisasi dan Pembobotan Faktor-Faktor Strategis Lingkungan Internal Kekuatan dan Kelemahan}

Berdasarkan hasil analisis lingkungan internal dengan kuisioner kepada 24 orang pedagang daging sapi dan 5 orang tokoh kunci (Lampiran 2), maka diperoleh beberapa faktor strategi internal yang berupa kekuatan dan kelemahan pengembangan pemasaran daging sapi di Kecamatan Kuala Simpang Kabupaten Aceh Tamiang. Adapun faktor-faktor strategis internal yang dipilih responden menjadi kekuatan (Strengths) bagi pengembangan pemasaran daging sapi di Kecamatan Kuala Simpang Kabupaten Aceh Tamiang adalah sebagai berikut :
1) Produk daging sapi berkualitas

2) Tenaga kerja tersedia

3) Peralatan semi modern

4) Kapasitas produksi besar

5) Pelayanan pasar yang baik

6) Adanya manajemen mutu

Sedangkan faktor-faktor strategi internal yang menjadi kelemahan (Weaknesses) bagi pengembangan pemasaran daging sapi di Kecamatan Kuala Simpang Kabupaten Aceh Tamiang adalah sebagai berikut :

1) Produksi daging sapi belum optimal

2) Kurangnya promosi

3) Harga jual daging sapi relatif tinggi

4) Biaya produksi daging sapi makin mahal

Hasil penskoran faktor strategis internal kekuatan dan kelemahan dapat dilihat pada Lampiran 2.

Inventarisasi dan Pembobotan Faktor-Faktor Strategis Lingkungan Eksternal Peluang dan Ancaman

Berdasarkan hasil analisis lingkungan eksternal melalui kuisioner kepada 24 orang pedagang daging sapi dan 5 orang tokoh kunci (Lampiran 2), maka diperoleh beberapa faktor strategi eksternal yang berupa peluang dan ancaman bagi pengembangan pemasaran daging sapi di Kecamatan Kuala Simpang Kabupaten Aceh Tamiang. Adapun faktor-faktor strategi eksternal yang dipilih responden menjadi peluang (Opportunities) bagi pengembangan pemasaran daging sapi di Kecamatan Kuala Simpang Kabupaten Aceh Tamiang, antara lain:

1) Meningkatnya permintaan daging sapi

2) Meningkatnya pendapatan konsumen

3) Meningkatnya konsumsi daging sapi konsumen

4) Pertumbuhan ekonomi membaik

5) Hubungan baik dengan pemasok

6) Potensi pengembangan ternak sapi

Sedangkan faktor-faktor strategi eksternal yang menjadi ancaman (Treaths) bagi pengembangan pemasaran daging sapi di Kecamatan Kuala Simpang Kabupaten Aceh Tamiang, antara lain:

1) Naik turunya nilai tukar rupiah

2) Inflasi (kenaikkan harga barang)

3) Naiknya harga BBM

4) Adanya barang pengganti

5) Daging sapi impor

Analisis Matrik EFI (Evaluasi Faktor Internal) dan EFE (Evaluasi Faktor Eksternal)

\section{Analisis Matrik EFI}

Setelah diperoleh faktor-faktor strategi internal pengembangan pemasaran daging sapi 
di Kecamatan Kuala Simpang Kabupaten Aceh Tamiang yang meliputi kekuatan dan kelemahan, dilakukan juga pemberian kuisioner kepada lima responden tokoh kunci, yaitu Kepala Dinas Pasar Kabupaten Aceh Tamiang, Kepala Dinas Pertanian dan Peternakan Kabupaten Aceh Tamiang, Ketua Pedagang Daging Sapi Pasar Kuala Simpang dan Akademisi sebanyak 2 Orang. Pengisian kuesioner ini tidak hanya melibatkan pihak internal (Dinas terkait) tetapi juga melibatkan pihak luar (Akademisi) Kecamatan Kuala Simpang, sehingga hasil pengisian kuesioner lebih bersifat objektif.

Kuisioner diisi oleh masing-masing responden untuk pembobotan dengan menggunakan paired comparison matrix. Selanjutnya dilakukan peringkatan untuk masing-masing variabel kekuatan dan kelemahan. Adapun pembobotan dan peringkatan pada variabel kekuatan dan kelemahan untuk masing-masing responden dapat dilihat pada Lampiran 3. Setelah diperoleh hasil pembobotan dan peringkatan untuk masing-masing responden, dilanjutkan dengan pencarian nilai rata-rata hasil pembobotan dan peringkatan dari seluruh responden, dengan cara membagi hasil penjumlahan seluruh nilai pembobotan atau peringkatan dari seluruh responden untuk masing-masing variabel kekuatan dan kelemahan dengan jumlah responden.

Adapun nilai rata-rata hasil pembobotan dan peringkatan untuk variabel kekuatan dan kelemahan pada pengembangan pemasaran daging sapi di Kecamatan Kuala Simpang Kabupaten Aceh Tamiang dapat dilihat di Lampiran 4. Setelah diperoleh nilai bobot dan peringkat rata-rata dari tiap variabel, dapat diketahui bobot skor rata-rata dari tiap variabel. Nilai ini merupakan perkalian antara bobot ratarata dengan peringkat rata-rata. Tabel IV.1 berikut ini merupakan hasil analisis matriks EFI pada pengembangan pemasaran daging sapi di Kecamatan Kuala Simpang Kabupaten Aceh Tamiang.

Tabel. IV.1. Hasil Analisis Matriks EFI (Evaluasi Faktor Internal)

\begin{tabular}{|l|l|l|l|}
\hline Faktor-faktor Strategis Internal & Bobot & Rating & \multicolumn{2}{l|}{$\begin{array}{l}\text { Silai } \\
\text { Skor }\end{array}$} \\
\hline 1 & 2 & & 4 \\
\hline Strengths (S)/Kekuatan & \multicolumn{2}{l|}{} \\
\hline Produk daging sapi berkualitas & 0.121 & 4.000 & 0.484 \\
\hline Tenaga kerja tersedia & 0.128 & 3.800 & 0.486 \\
\hline Peralatan semi modern & 0.119 & 4.000 & 0.476 \\
\hline Kapasitas produksi besar & 0.125 & 3.400 & 0.425 \\
\hline Pelayanan pasar yang baik & 0.121 & 3.400 & 0.411 \\
\hline Adanya manajemen mutu & 0.121 & 4.000 & 0.484 \\
\hline Sub total & 0.735 & & 2.767 \\
\hline Weaknesses (W)/Kelemahan & & & \\
\hline Produksi daging sapi belum optimal & 0.064 & 2.000 & 0.128 \\
\hline Kurangnya promosi & 0.068 & 1.200 & 0.082 \\
\hline Harga jual daging sapi relatif tinggi & 0.068 & 1.400 & 0.095 \\
\hline Biaya produksi daging sapi makin tinggi & 0.066 & 1.400 & 0.092 \\
\hline Sub total & 0.266 & & 0.397 \\
\hline Total & 1.000 & & 3.164 \\
\hline Sumber: Data Primer (diolah), 2015 & & \\
\hline
\end{tabular}

Sumber: Data Primer (diolah), 2015

Dari hasil analisis EFI faktor kekuatan (S) mempunyai nilai 2,767 sedangkan faktor kelemahan (W) mempunyai nilai 0,397 ini berarti dalam pengembangan pemasaran daging sapi di Kecamatan Kuala Simpang Kabupaten Aceh Tamiang masih mempunyai faktor kekuatankekuatan yang lebih baik dari pada faktor kelemahan-kelemahan yang ada.

\section{Analisis Matriks EFE}

Setelah diperoleh faktor-faktor strategis eksternal pada pengembangan pemasaran daging sapi di Kecamatan Kuala Simpang Kabupaten Aceh Tamiang yang meliputi faktor peluang dan ancaman, dilanjutkan pengisian kuisioner kepada ke lima responden tokoh kunci seperti halnya pengisian kuisioner untuk lingkungan internal. Untuk pemberian bobot 
pada variabel peluang dan ancaman juga menggunakan paired comparison matrix.

Selanjutnya dilakukan peringkatan untuk masing-masing variabel peluang dan ancaman. Adapun pembobotan dan peringkatan pada variabel peluang dan ancaman untuk masing-masing responden dapat dilihat pada Lampiran 7.

Setelah diperoleh hasil pembobotan dan peringkatan untuk masing-masing responden, dilanjutkan dengan pencarian nilai rata-rata hasil pembobotan dan peringkatan dari seluruh responden, dengan cara membagi hasil penjumlahan seluruh nilai pembobotan atau peringkatan dari seluruh responden untuk masing-masing variabel peluang dan ancaman Tabel IV.2. Hasil Analisis Matriks EFE (Evaluasi Faktor Eksternal)

\begin{tabular}{|l|l|l|l|}
\hline Faktor-faktor Strategis Eksternal & Bobot & Rating & Nilai \\
\cline { 3 - 4 } & \multicolumn{2}{l|}{ Skor } \\
\hline 1 & 2 & 3 & 4 \\
\hline Opportunities (0)/Peluang & \multicolumn{2}{l|}{} \\
\hline Meningkatnya permintaan daging sapi & 0.105 & 3.800 & 0.399 \\
\hline Meningkatnya pendapatan konsumen & 0.117 & 4.000 & 0.468 \\
\hline Meningkatnya konsumsi daging sapi konsumen & 0.100 & 3.000 & 0.300 \\
\hline Pertumbuhan ekonomi membaik & 0.121 & 3.400 & 0.411 \\
\hline Hubungan baik dengan pemasok & 0.112 & 3.600 & 0.403 \\
\hline Potensi pengembangan ternak sapi & 0.107 & 3.200 & 0.342 \\
\hline Sub total & 0.662 & \multicolumn{2}{l|}{} \\
\hline Treaths (T)/Ancaman & \multicolumn{3}{l|}{} \\
\hline Naik turunnya nilai tukar rupiah & 0.073 & 1.800 & 0.131 \\
\hline Inflasi (kenaikkan harga barang) & 0.074 & 1.200 & 0.089 \\
\hline Naiknya harga BBM & 0.063 & 2.000 & 0.126 \\
\hline Adanya barang pengganti & 0.063 & 1.000 & 0.063 \\
\hline Daging sapi impor & 0.065 & 1.000 & 0.065 \\
\hline Sub Total & 0.338 & & 0.474 \\
\hline Total & 1.000 & & 2.798 \\
\hline Sumber: Data Primer (dion
\end{tabular}

Sumber: Data Primer (diolah), 2015

Dari hasil analisis EFE menunjukkan bahwa untuk faktor-faktor peluang (0) nilai skornya 2,324 dan faktor-faktor ancaman ( $T$ ) nilai skornya 0,474 ini berarti bahwa dalam pengembangan pemasaran daging sapi di Kecamatan Kuala Simpang Kabupaten Aceh Tamiang masih memiliki peluang untuk dikembangkan, mengingat faktor ancamannya lebih kecil dari faktor peluang. Dengan

Tabel IV.3. Hasil Analisis Matriks EFI dan EFE

\begin{tabular}{|l|l|l|}
\hline EFI \& EFE & Strengths (S) & Weaknesses (W) \\
\hline Opportunities (O) & Strategi (SO) & Strategi (WO) \\
$=2,767+2,324$ & $=0,397+2,324$ \\
$=5,091$ & $=2,721$ \\
\hline Treahts (T) & Strategi (ST) & Strategi (WT) \\
& $=2,767+0,474$ & $=0,397+0,474$ \\
& $=3,241$ & $=0,871$ \\
\hline
\end{tabular}

Sumber: Data Primer (diolah), 2015

AGRISAMUDRA, Jurnal Penelitian Vol.2 No. 2 Juli-Desember 2015 faktor internal dan eksternal sebagai berikut:

- $\quad$ Faktor kekuatan $(\mathrm{S}) \quad=2,767$

- $\quad$ Faktor Kelemahan (W) =0,397

- $\quad$ Faktor Peluang $(0) \quad=2,324$

- $\quad$ Faktor Ancaman (T) $=0,474$ matriks EFI dan EFE sebagai berikut: dengan jumlah responden. Adapun nilai rata-rata hasil pembobotan dan peringkatan untuk variabel peluang dan ancaman pada pengembangan pemasaran daging sapi di Kecamatan Kuala Simpang Kabupaten Aceh Tamiang di Lampiran 8.

Setelah diperoleh nilai bobot dan peringkat rata-rata dari tiap variabel, dapat diketahui bobot skor rata-rata dari tiap variabel. Nilai ini merupakan perkalian antara bobot ratarata dengan peringkat rata-rata. Tabel IV.2 berikut ini merupakan hasil analisis matriks EFE pada pengembangan pemasaran daging sapi di Kecamatan Kuala Simpang Kabupaten Aceh Tamiang.

tersusunnya matriks EFI dan EFE tersebut dapat menghasilkan nilai skor pada masing-masing

Yang dapat digambarkan dalam rumusan 
Tabel IV.3 di atas menunjukkan bahwa strategi SO memiliki skor lebih tinggi dibanding dengan WO. Kemudian strategi ST memiliki skor lebih besar dari ST. Kesimpulannya adalah pengembangan pemasaran daging sapi masih memungkinkan untuk dilakukan karena faktor kekuatan dan pelauang mempunyai nilai paling besar dari faktor kelemahan dan ancaman.

Analisis Matriks SWOT
Analisis matriks SWOT menggunakan data yang telah diperoleh dari matriks EFI dan EFE. Empat strategi utama yang disarankan yaitu strategi SO (strength and opportunities), WO (weakness and opportunities), ST (strength and threats) dan WT ( weakness and threats). Adapun hasil analisis matriks SWOT dapat dilihat pada Lampiran 11.

Matriks SWOT strategi pengembangan pemasaran daging sapi di Kecamatan Kuala Simpang Kabupaten Aceh Tamiang di sajikan pada gambar 3 berikut:

\begin{tabular}{|c|c|c|}
\hline EFE & \begin{tabular}{ll}
\multicolumn{2}{l}{ Strengths (S) } \\
1. Produk daging sapi \\
berkualitas \\
2. Tenaga kerja tersedia \\
3. Peralatan semi modern \\
4. Kapasitas produksi \\
besar \\
5. Pelayanan pasar yang \\
baik \\
6. Adanya manajemen \\
mutu
\end{tabular} & $\begin{array}{l}\text { Weaknesses }(\mathbf{W}) \\
\text { 1. Produksi daging sapi belum } \\
\text { optimal } \\
\text { 2. Kurangnya promosi } \\
\text { 3. Harga jual daging sapi relatif } \\
\text { tinggi } \\
\text { 4. Biaya produksi daging sapi } \\
\text { makin mahal }\end{array}$ \\
\hline $\begin{array}{l}\text { Opportunities (0) } \\
\text { 1. Meningkatnya } \\
\text { permintaan daging sapi } \\
\text { 2. Meningkatnya } \\
\text { pendapatan konsumen } \\
\text { 3. Meningkatnya konsumsi } \\
\text { daging sapi konsumen } \\
\text { 4. Pertumbuhan ekonomi } \\
\text { membaik } \\
\text { 5. Hubungan baik dengan } \\
\text { pemasok } \\
\text { 6. Potensi pengembangan } \\
\text { ternak sapi }\end{array}$ & $\begin{array}{l}\text { STRATEGI S-0 } \\
\text { 1. Meningkatkan } \\
\text { permintaan daging sapi } \\
\text { dengan menciptakan } \\
\text { produk berbasis daging } \\
\text { sapi ( } 1, \mathrm{~S} 2, \mathrm{S3}, \mathrm{S4,S5,} \\
01,02,03,06) \\
\text { 2. Mengembangkan sistem } \\
\text { pemasaran yang bisa } \\
\text { mencukupi semua } \\
\text { kebutuhan konsumen } \\
\text { (S1, S3, S5, S6, 02, 03, } \\
\text { 05, 06) }\end{array}$ & $\begin{array}{l}\text { STRATEGI W-0 } \\
\text { 5. Meningkatkan kerjasama } \\
\text { dengan pemasok agar } \\
\text { mendapatkan harga yang } \\
\text { kompetitif (W1, W2, W4, 01, } \\
\text { 03, 04, 06) } \\
\text { 6. Mengembangkan promosi } \\
\text { dan peternakan sapi untuk } \\
\text { meningkatkan pasokan } \\
\text { daging sapi lokal yang } \\
\text { berkualitas (W4, W5, W6, } \\
\text { 01, 02, 03, 04, 05, 06) }\end{array}$ \\
\hline $\begin{array}{l}\text { Treaths (T) } \\
\text { 1. Naik turunnya nilai tukar } \\
\text { rupiah } \\
\text { 2. Inflasi (kenaikkan harga } \\
\text { barang) } \\
\text { 3. Naiknya harga BBM } \\
\text { 4. Adanya barang } \\
\text { pengganti } \\
\text { 5. Daging sapi impor }\end{array}$ & $\begin{array}{l}\text { STRATEGI S-T } \\
\text { 1. Meningkatkan sosialisasi } \\
\text { manfaat daging sapi lokal } \\
\text { (S1, S2, S3, S7, T1, T2, } \\
\text { T3, T4) } \\
\text { 2. Membentuk koperasi } \\
\text { pedagang daging sapi } \\
\text { agar tidak ada perbedaan } \\
\text { harga yang terlalu besar } \\
\text { (S2, S3, S5, T1, T3, T6) }\end{array}$ & $\begin{array}{l}\text { STRATEGI W-T } \\
\text { 7. Mengadakan perluasan } \\
\text { pasar daging sapi (W2, W3, } \\
\text { W5, T1, T2, T3) } \\
\text { 8. Meningkatkan kwalitas } \\
\text { SDM peternak sapi lokal } \\
\text { (W2, W3, W5, W6, 01, 03, } \\
\text { 06) }\end{array}$ \\
\hline
\end{tabular}

\section{Gambar 1. Hasil Analisis Matriks SWOT Pengembangan Pemasaran Daging Sapi Di Kuala Simpang}

\section{Pengambilan Keputusan}

Setelah diperoleh beberapa alternatif strategi melalui tahap pencocokan, yaitu dengan menggunakan matriks EFI/EFE dan matriks SWOT, maka tahap akhir dari analisis formulasi strategi adalah pemilihan strategi yang terbaik. Adapun alat analisis yang digunakan pada tahap pengambilan keputusan ini adalah Matriks Perencanaan Strategi Kuantitatif (Quantitative Strategic Planning Matrix/QSPM). Teknik ini menggunakan input dari analisis tahap masukan dan hasil pencocokan dari analisis tahap pemaduan untuk menentukan secara objektif diantara alternatif strategi.
Secara konsep, QSPM menentukan daya tarik relatif dari berbagai strategi berdasarkan seberapa jauh faktor strategis internal dan eksternal dimanfaatkan atau diperbaiki. Nilai AS (Attractiveness Score) menunjukkan daya tarik masing-masing strategi terhadap faktor kunci internal dan eksternal perusahaan. Nilai AS diperoleh melalui kuisioner yang ditujukan kepada kelima responden yaitu Kepala Dinas Pasar Kabupaten Aceh Tamiang, Kepala Dinas Pertanian dan Peternakan Kabupaten Aceh Tamiang, Ketua Pedagang Daging Sapi Pasar Kuala Simpang dan Akademisi. Nilai TAS (Total Attractiveness Scores) 
dari masing-masing responden diperoleh dari hasil perkalian antara bobot rata-rata dan nilai AS dari setiap faktor kunci strategis.

Kemudian dilanjutkan perhitungan nilai STAS (Sum Total Attractiveness Scores), dari masing-masing responden dengan cara menjumlahkan seluruh nilai TAS dari masingmasing faktor internal dan eksternal. Adapun perhitungan QSPM dari masing-masing responden dapat dilihat pada Lampiran 10. Selanjutnya, setelah diperoleh nilai STAS dari masing-masing responden kemudian dilanjutkan perhitungan nilai STAS rata-rata dari seluruh responden dengan cara membagi hasil penjumlahan STAS dari seluruh responden dengan jumlah responden. Adapun hasil perhitungan STAS rata-rata untuk melihat prioritas strategi pada pengembangan pemasaran daging sapi di Kecamatan Kuala Simpang Kabupaten Aceh Tamiang dapat dilihat pada Tabel IV.4.

Tabel IV.4. Prioritas Strategi pada Pengembangan pemasaran daging sapi di Kecamatan Kuala Simpang Kabupaten Aceh Tamiang

\begin{tabular}{|l|l|l|l|l|l|l|l|l|}
\hline & \multicolumn{2}{|l|}{ STRATEGI } & \multicolumn{10}{l|}{} \\
\cline { 2 - 9 } & 1 & 2 & 3 & 4 & 5 & 6 & 7 & 8 \\
\hline STAS 1 & 5.665 & 5.245 & 5.483 & 6.060 & 5.550 & 5.792 & 5.953 & 6.010 \\
STAS 2 & 5.870 & 5.628 & 5.538 & 5.130 & 5.646 & 5.977 & 5.480 & 5.589 \\
STAS 3 & 5.638 & 5.292 & 5.301 & 5.865 & 5.580 & 5.575 & 5.749 & 5.806 \\
STAS 4 & 5.593 & 5.080 & 5.468 & 5.922 & 5.535 & 5.696 & 5.820 & 5.927 \\
STAS 5 & 5.600 & 5.072 & 5.413 & 5.910 & 5.542 & 5.634 & 5.870 & 5.870 \\
& 5.673 & 5.263 & 5.441 & 5.777 & 5.571 & 5.735 & 5.774 & 5.840 \\
\hline Urutan Prioritas & 5 & 8 & 7 & 2 & 6 & 4 & 3 & 1 \\
Strategi & 5 & 8 & 7 & 2 & 6 & & & \\
\hline
\end{tabular}

Sumber: Data Primer (diolah), 2015

Keterangan:

- $\quad$ STAS1 = Hasil perhitungan jawaban responden Kadis Pasar

- $\quad$ STAS2 = Hasil perhitungan jawaban responden Kadis Pertanian dan Peternakan

- $\quad$ STAS 3 = Hasil perhitungan jawaban responden Ketua Pedagang Daging Sapi

- $\quad$ STAS 4 = Hasil perhitungan jawaban responden Akademisi 2

- $\quad$ STAS 5 = Hasil perhitungan jawaban responden Akademisi 1

Adapun urutan prioritas strategi untuk pengembangan pemasaran daging sapi di Kecamatan Kuala Simpang Kabupaten Aceh Tamiang adalah sebagai berikut :

1. Meningkatkan kerjasama dengan pemasok agar mendapatkan harga yang kompetitif (STAS rata-rata $=5,840$ )

2. Meningkatkan kwalitas SDM peternak sapi lokal (STAS rata-rata $=5,777$ )

3. Mengadakan perluasan pasar daging sapi (STAS rata-rata $=5,774$ )

4. Mengembangkan sistem pemasaran yang bisa mencukupi semua kebutuhan konsumen (STAS rata-rata $=5,735$ )

5. Mengembangkan promosi dan peternakan sapi untuk meningkatkan pasokan daging sapi lokal yang berkualitas (STAS rata-rata $=$ 5,673)

6. Membentuk koperasi pedagang daging sapi agar tidak ada perbedaan harga yang terlalu besar (STAS rata-rata $=5,571$ )

7. Meningkatkan sosialisasi manfaat daging sapi lokal (STAS rata-rata $=5,441$ )
8. Meningkatkan permintaan daging sapi dengan menciptakan produk berbasis daging sapi (STAS rata-rata $=5,263$ )

\section{KESIMPULAN DAN SARAN}

\section{Kesimpulan}

1. Hasil analisis faktor-faktor strategis internal pengembangan pemasaran daging sapi di Kecamatan Kuala Simpang terdiri dari; 1) Faktor kekuatan: Produk daging sapi berkualitas, Tenaga kerja tersedia, Peralatan semi modern, Kapasitas produksi besar, Pelayanan pasar yang baik dan Adanya manajemen mutu. 2) Faktor kelemahan:, Produksi daging sapi belum optimal, Kurangnya promosi, Harga jual daging sapi relatif tinggi dan Biaya produksi daging sapi makin mahal.

2. Hasil analisis faktor-faktor strategis eksternal pengembangan pemasaran daging sapi di Kecamatan Kuala Simpang terdiri dari; 1) Faktor peluang: Meningkatnya permintaan daging sapi, Meningkatnya pendapatan konsumen, Meningkatnya konsumsi daging 
sapi konsumen, Pertumbuhan ekonomi membaik, Hubungan baik dengan pemasok dan Potensi pengembangan ternak sapi. 2) Faktor ancaman: Naik turunya nilai tukar rupiah, Inflasi (kenaikkan harga barang), Naiknya harga BBM, Adanya barang pengganti, Daging sapi impor.

3. Hasil analisis SWOT alternatif prioritas yang ditawarkan dalam rangka pengembangan pemasaran daging sapi di Kecamatan Kuala Simpang adalah:

- Meningkatkan kerjasama dengan pemasok agar mendapatkan harga yang kompetitif (STAS $=5,840$ )

- $\quad$ Meningkatkan kwalitas SDM peternak sapi lokal (STAS $=5,777$ )

- Mengadakan perluasan pasar daging sapi (STAS $=5,774$ )

- Mengembangkan sistem pemasaran yang bisa mencukupi semua kebutuhan konsumen (STAS $=5,735$ )

- Mengembangkan promosi dan peternakan sapi untuk meningkatkan pasokan daging sapi lokal yang berkualitas (STAS $=5,673$ )

- Membentuk koperasi pedagang daging sapi agar tidak ada perbedaan harga yang terlalu besar (STAS $=5,571$ )

- Meningkatkan sosialisasi manfaat daging sapi lokal (STAS $=5,441$ )

- Meningkatkan permintaan daging sapi dengan menciptakan produk berbasis daging sapi $($ STAS $=5,263$ )

\section{Saran}

Untuk dapat melaksanakan strategi alternatif yang ditawarkan diperlukan syarat-syarat sebagai berikut:

1. Koordinasi Dinas terkait dalam pengembangan pemasaran daging sapi dalam rangka meningkatkan kesejahteraan pedagang daging sapi serta masyrarakat peternak sapi Kecamatan Kuala Simpang khususnya dan Kabupaten Aceh Tamiang pada umumnya.

2. Kesesuaian program antara dinas pasar dan dinas pertanian dan peternakan dengan dinas lain yang terkait di tingkat kecamatan dan tingkat kabupaten.

3. Diperlukan penelitian lanjutan mengenai pemasaran daging sapi agar diperoleh hasil penelitian yang dapat dijadikan pembanding terhadap penelitian ini.

4. Diperlukan kebijakan pembangunan dari pemerintah pusat, propinsi maupun pemerintah kabupaten dan kecamatan.

\section{DAFTAR PUSTAKA}

Ali Muhammad. 2003. Penelitian Pendidikan Prosedur dan Strategi. Jakarta : Pustaka Aman.
Arbi, P. 2009. Analisis Kelayakan dan Strategi Pengembangan Usaha Ternak Sapi Potong (Studi Kasus Desa Kesuma Kecamatan Namo Rambe Kabupaten Deli Serdang). Skripsi. Fakultas Pertanian Universitas Sumatra Utara, Medan.

Basu Swastha, 2002. Manajemen Pemasaran Modern. BPFE. Yokyakarta

David, L. 2002. Pengantar Perencanaan dan Pembangunan Ekonomi Daerah. BPFE, Yokyakarta.

Desrosier,N.W. 1988. Teknologi Pengawetan Pangan. UI. Press. Jakarta

Forest, J.C., Aberle E.D., Hedrick H.B, Judge M.D. and Merkel R.A. 2007. Principles of Meat Science. W.H. Freeman and Company, San Fransisco.

Gitosudarmo, 2000. Manajemen Pemasaran, BPFE- Yogyakarta, Yogyakarta.

Hamel, G dan Prahalad, C, K, 1995. Kompetisi Masa Depan. Yakarta : Bina Rupa Aksara.

Harper W. 2000. Manajemen Pemasaran Suatu Pendekatan Strategis dengan Orientasi Global, Erlangga, Jakarta.

Hatten, Kenneth J., 1996, Effective Strategic Management, Prentice Hall, Engelwoods Cliff.

Jauch Lawrence R. \& Glueck William F., (1989), 'Manajemen Dan Strategis Kebijakan Perusahaan', Jakarta : Erlangga.

Kotler, Philip. 1997. Manajemen Pemasaran di Indonesia, Salemba Empat, Jakarta.

Kotler, Philip. 2006. Manajemen Pemasara : Analisis, Perencanaan, mplementasi dan Kontrol, terj : Hendra Teguh dan Ronny Antonius Rusly, Edisi 9, Jilid 1 dan 2, PT Prenhalindo, Jakarta.

Lawrie RA. 2003. IImu Daging. Terjemahan: Aminuddin Parakkasi. Penerbit Universitas Indonesia Press, Jakarta.

Nazir, Moh. 2005. Metode Penelitian. Cetakan Pertama. Penerbit Ghalia Indonesia. Jakarta.

Ohmae, K., 1999. Putting Global Logic First, Harvard Business Review

Pearce, J., dan Robinson, R. (1997) Strategic Management:formulation, Implementation, and Control, 7th Edition, McGraw-Hill, Malaysia. 
Priyanto, D. 2011. Strategi Pengembangan Ternak Sapi dan Kerbau dalam Mendukung PSDS Tahun 2014. Jurnal Penelitian dan Pengembangan Pertanian. Balai Penelitian Ternak, Bogor. 30(3): 108-116.

Rangkuti, F. 1998. Analisis SWOT Teknik Membedah Kasus Bisnis. Gramedia Pustaka Utama, Jakarta.
Robert M. Grant. 1997. Analisis Strategi Kontemporer. Konsep, Teknik, Aplikasi. Penerbit Erlangga. Jakarta.

Suryana. 2009. Kewirausahaan, Pedoman Praktis, Kiat Dan Proses Menuju Sukses. Edisi Revisi. SALEMBA EMPAT, Jakarta.

Sudarmono, A.S dan Sugeng, Y.B., 2008. Sapi Potong. Penebar Swadaya. Jakarta.

Soeparno. 1994. IImu dan Teknologi Daging. Gajah Mada University, Yogyakarta. 